\title{
Znalostní management jako nástroj pro podporu znalostí v průmyslovém podniku
}

\author{
Martin Ambros ${ }^{1}$, Filip Knapp ${ }^{1}$, Jana Kleinová ${ }^{1}$ \\ ${ }_{1}$ Západočeská univerzita v Plzni, Fakulta strojní, Katedra průmyslového inženýrství a \\ managementu \\ Univerzitní 2732/8, 30614 Plzeň, Česká republika \\ ambros@kpv.zcu.cz \\ fknapp@kpv.zcu.cz \\ kleinova@kpv.zcu.cz
}

\begin{abstract}
Anotace: Článek pojednává o Znalostním managementu jako nástroji pro podporu znalostí - přináší definici pojmu, vysvětlení konceptu a jeho stručnou historii spolu s uvedením jednotlivých druhů znalostí. Dále se zaobírá koncepty znalostního managementu, jeho oblastech a syntézou znalostí. Závěrem popisuje problematiku rozpočtu aktivit znalostního managementu spolu s definicí cílů a problematiku tvorby týmu.
\end{abstract}

\section{1 Úvod}

V současné vysoce konkurenční a globalizované době se společnosti více než kdy dřive musí zaměřovat na vlastní zefektivňování procesủ, snižování nákladů a potřebou inovovat. To vše současně s potřebou vypořádat se s nepřeberným množstvím informací a potřebou tyto informace vhodně vytvářet, uchovávat, sdílet a poskytovat správným lidem ve správný čas. To vše vytváří tlak na tzv. znalostně rízenou organizaci. $V$ neposlední řadě, z pohledu managementu podniku, jde o znalostní podporu pracovníků organizace, díky které jsou schopni inovovat, zlepšovat procesy či vytvářet produkty a služby efektivněji s nižšími náklady. Konceptem, který se zaobírá řízením organizace na bázi znalostí, je znalostní management.

\section{Znalostní management}

Termín Znalostní management vznikl překladem anglického výrazu „knowledge management“, který prišsel z anglosaských zemí. V českém prostředí je možné se setkat i s výrazem management znalostí, který se ovšem od termínu znalostní management, ač zní podobně, liší. Management znalostí je základem znalostního managementu, jeho podmnožinou. [2]

Zrod znalostního managementu, který se objevil zhruba na počátku 90.let, se vyvinul z potřeby vypořádat se s komplexitou současného informačního věku a s potřebou čelit stále rostoucí konkurenci vyvolané novými technologiemi a stále se zvyšujícími nároky zákazníků. Nejprve byla uznána důležitost informací a znalostí, následovaná hledáním způsobů, jak vytvářet, ukládat, integrovat, přizpůsobovat, sdílet a zpř́stupňovat správné znalosti správným 
lidem ve správný čas. To vše, spolu se všeobecně uznávanou potřebou zvyšovat úroveň znalostí pracovníků, vytvárí tlak na znalostně řízenou organizaci. [1]

Z pohledu managementu organizace jde zejména o podporu znalostí zaměstnanců, díky čemuž jsou schopni vytvářet nové nápady a následně je používat, což znamená značnou konkurenční výhodu. Tito zaměstnanci jsou označování jako znalostní pracovníci. [3]

\subsection{Znalost jako základní součást znalostního managementu}

Znalost, jako základní součást znalostního managementu, bývá uváděna $v$ literatuře jako instinkty, ideje, pravidla a procedury, které vedou akce a rozhodnutí. S pojmem znalost úzce souvisí data, informace a moudro. Jejich celkový vztah charakterizuje následující obrázek. [2]

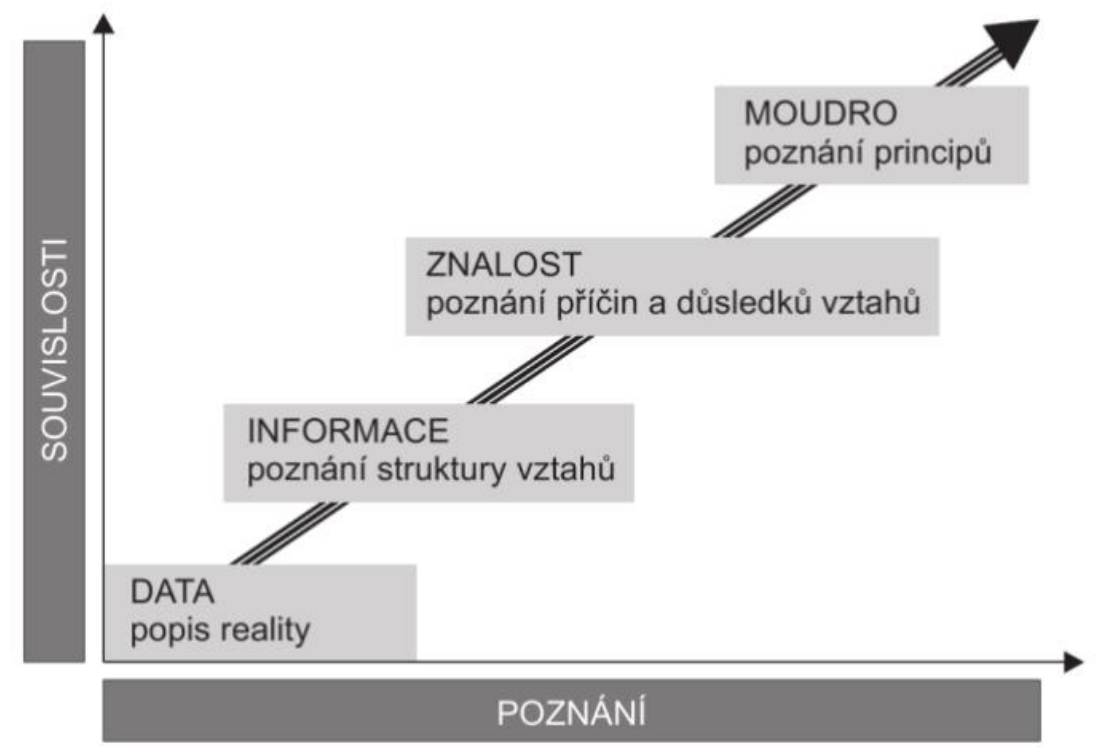

Obrázek 1 - základní pojmy a jejich vztah

Existují tři základní druhy znalostí, které jsou v literatuře definovány takto:

- Explicitní znalost - formalizovaná, nebo dokumentovaná znalost, která je snadno přenositelná. Převážně je zpracovávána pomocí informačních prostředků. Jedná se o dokumenty, manuály apod.

- Implicitní znalost - znalost, která je uchovávána $v$ mysli daného jedince a je možné ji převést do explicitní formy. Jedná se např. o znalost procesu či návod na provedení určité akce.

- Tacitní znalost - znalost, která je stejně jako znalost implicitní uchovávána $v$ mysli daného jedince. Ve většině prípadů je obtížné či přímo nemožné ji prevést do explicitní formy a zdokumentovat ji. Jedná se o získané zkušenosti či například znalost experta $v$ určité oblasti. [1] [2]

Znalost je možno vidět na několika úrovních. Nejčastěji se Ize setkat s následujícími: 
- Nadnárodní úroveň - nejširší a nejobecnější úroveň, která vytváří základní rámec pro úrovně nižší. $V$ této úrovni je možné se setkat $s$ široce rozšířenými pojmy, jako jsou "Znalostí ekonomika“ nebo „Znalostní společnost“. Jedná se o úroveň nad rámec dané země

- Národní úroveň - úroveň v rámci daného státu

- Organizační úroveň - tato úroveň již označuje organizace, které se snaží o znalostně orientované rízení organizace. Realizují tudíž "znalostní management"

- Úroveň managementu znalostí - nejnižší úroveň, obsahující metody, techniky, principy či postupy využívané při práci se znalostmi či jednotlivé metody, jak informace získat (data mining, shánění informací, strojové učení apod.). Výstupy z této úrovně nacházejí uplatnění na organizační úrovni. [2]

Na základě uvedených úrovní je třeba konstatovat, že čím se dostáváme na vyšší úroveň, tím je vyšší úroveň obecnosti. Na úrovni managementu znalostí se pracuje s konkrétními znalostmi, zatímco na vyšších úrovních jde spíše o vytváření prostředí či rámce pro jejich sdílení, rozvoj, využívání apod. [2]

\subsection{Historický vývoj znalostního managementu}

Znalosti a práce s nimi je lidstvu známa od nepaměti. Znalosti se předávaly ústně $z$ člověka na člověka, $z$ generace na generaci. Vždy se $k$ původním znalostem či dovednostem príidaly nové. Tyto znalosti se ukládaly do rozličných forem, např. do přiběhů či pohádek. Účelem bylo převážně vlastní přežití. Jednalo se o tzv. učení se ze zkušeností. [1] [2]

Postupem času, s vývojem lidské společnosti, se začala rozvíjet potřeba práce se znalostmi nejen pro vlastní přežití. Vznik Znalostního managementu, tak jak ho známe dnes, se datuje zhruba od 90 . let minulého století. Poprvé termín „Knowledge Management“ použil K. Wiig v roce 1986, ve své práci o využití umělé inteligenci při řízení znalostí. $V$ počátcích 90 . let se společnosti shodly, že znalosti jsou $v$ jejich společnostech tím nejdůležitějším aktivem. Nicméně neměli ponětí, jak je řídit. Postupně začaly vznikat na téma znalostního managementu odborné publikace a společnosti se snažily nalézt technologickou bázi pro jejich řizení, sdílení a uchovávání. Od druhé poloviny devadesátých let se pojem masivně dostává do povědomí široké veřejnosti. V roce 1996 vznikla první asociace znalostního managementu - The European Knowledge Management Association. Množství publikací se rok od roku rozrůstá včetně rozličných metodik zavádění znalostního managementu, specializujících se na různé možnosti aplikace. [1] [2]

\subsection{Definice Znalostního managementu a jeho oblasti}

Definice či vymezení pojmu znalostního managementu je velmi široké. Existuje mnoho definic či charakteristik, které ho popisují. Volně Ize uvést znalostní management jako chytání kolektivní podnikové odbornosti. [3] Asi nejkomplexněji charakterizuje pojem následující definice: „Znalostní management je způsob manažerského prístupu $k$ vedení organizace, tvorby 
prostředí v organizaci a dosahování podnikových cílů, spočívající ve sladění organizačních procesů $s$ procesy znalostními, a to prostřednictvím znalostních zdrojů a pomocí vhodných metod, technik a nástrojū." [2]

Dle různých průzkumů vyšlo najevo, že se znalostní management týká šesti hlavních oblastí. $V$ závislosti na oboru podnikání a trhů se mohou lišit. Obecně je Ize uvést následovně:

- Spojování lidí

- Učení se ze zkušeností

- Zlepšení prístup $\mathrm{k}$ datům

- Uchovávání znalostí

- Vytváření nejlepších praktik

- Inovace

Znalostní management se považuje za další manažerskou disciplínu, prripodobnit se dá například $\mathrm{k}$ managementu řízení rizik či bezpečnostnímu managementu. Organizace, které s těmito oblastmi již mají zkušenost, mají potenciál tento koncept snadněji přijmout a implementovat. [4]

\subsection{Syntéza znalostí}

Velmi důležitým prvkem znalostního managementu je syntéza znalostí. Jedná se o přehled různých dat a informací $z$ nejrůznějších zdrojů, které jsou následně zdokumentovány do jednoho setu, který mohou využít ostatní pracovníci k řešení problému či jiných aktivit. Syntetizované znalosti se tak dají charakterizovat jako set strukturovaných materiálů z nejrůznějších zdrojů, za účelem jejich následného využití. Takto strukturované znalosti se skládají např. z následujících prvků:

- Procesní návodky

- Techniky a metody

- Kontrolní seznamy

- Designové návodky a principy

- Nejčastější otázky

- Šablony

- Př́íklady

- Tipy a rady

- Získané zkušenosti

Tyto informace jsou většinou uloženy na jednom místě $v$ organizaci, díky čemuž poskytují snadný přístup všem pracovníkům napříč organizací. Vždy je zapotřebí, aby existoval vlastník dané položky, který dbá na její správnost a aktuálnost. Technologie, $v$ které jsou informace uloženy a zpřístupněny, mohou být různorodé. Může se jednat o tzv. Wikis sítě či různé webové portály, jako např́klad Sharepoint. Velmi důležité je vytvořit takový systém, který bude snadno prístupný a bude $v$ něm možné informace rychle vyhledat. To umožní uchované informace vyvolat a znovu použít, což může přispět $k$ řešení nejrůznějších problémů v organizaci. [4] 


\section{$3 \quad$ Koncepty znalostního managementu}

Znalostní management je poměrně složitý koncept, nebot' je souhrnem poznatků z mnoha oblastí a vědních disciplín. Pro plné pochopení nabízí např. publikace Znalostní management a proces jeho zavádění, několik perspektiv, jak tento koncept vnímat a pracovat s ním. Tyto perspektivy, popsané níže, Ize rozšírit i na jiné, např. ekonomické. [2]

- Konceptuální perspektiva - jedná se o teoretickou rovinu pro zkoumání znalostního managementu. Týká se samotné definice znalosti a znalostního managementu či jeho celkového rámce [2]

- Procesní perspektiva - určena pro definování a pochopení jednotlivých znalostních procesů, které zajišt'ují realizaci znalostních aktivit. Pro znalostní procesy existují různé modely, príkladem může být jeden z nejzákladnějších dle Di Belly:

1. Získání znalostí

2. Rozšiřrení znalostí

3. Použití znalostí [2]

- Technologická perspektiva - $v$ této perspektivě jsou zkoumány především způsoby, jak mohou informační, komunikační a znalostní technologie pomoci při realizaci znalostního managementu. Jedná se o různé informační technologie, brainstorming, datové sklady, data mining apod. Infrastruktura v obecném slova syslu vytváŕí rámec pro jednotlivé procesy, které mají být realizovány [2]

- Organizační perspektiva - orientuje se na problematiku organizačních struktur a různých organizačních celků a jejich vazbám ke znalostnímu managementu [2]

- Implementační perspektiva - zaměřena na postupy a metody, jak zavést znalostní management do konkrétní organizace. Prostředkem jsou metodiky zavádění [2]

- Manažerská perspektiva - zabývá se manažerskými aspekty zavádění a realizací znalostního managementu ve společnostech. Součástí jsou taktéž diskuze o prínosech a benefitech konceptu [2]

\section{Tým znalostního managementu}

Pro implementaci a spuštění aktivit znalostního managementu jsou mimo jiné vyžadovány i lidské zdroje. Nejprve je třeba definovat velikost týmu, který se bude znalostním managementem zabývat. Jedná se o náročný úkol, nebot' stanovení optimálního počtu pracovníků závisí na velikosti organizace a současné úrovni znalostního managementu. Potřeba vyššího počtu pracovníků pro organizaci, která s tímto konceptem teprve začíná, je žrejmá. Průzkum společnosti Knoco Limited přináší pohled na velikost týmu $v$ závislosti na velkosti organizace. Graf je zobrazen na obrázku číslo 2. [4] 
FIGURE 6.1 A graph of KM team size for a variety of organizational size ranges

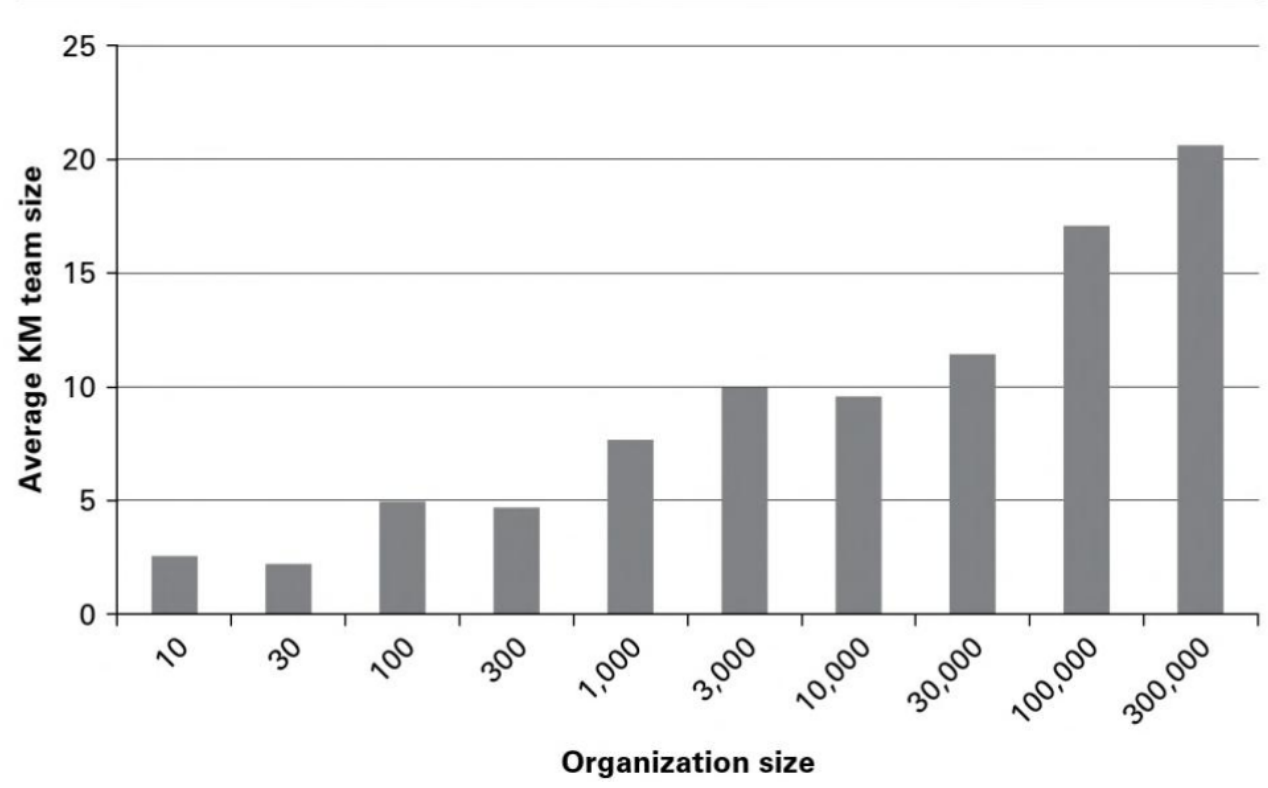

Obrázek 2 - Velikost týmu v závislosti na velikosti organizace [4]

Z grafu je zřejmá nelineární závislost počtu pracovníků na velikosti organizace, nebot' ji ovlivňuje mnoho faktorů.

Dalším důležitým aspektem týmu jsou znalosti a dovednosti, kterými by členové měli disponovat. Obecně se specifikuje sedm hlavních oblastí: [4]

- Praxe $v$ daném odvětví - pracovníci musí mít povědomí o oboru podnikání organizace. Příkladem může být právnická firma, $v$ níž je zásadní, aby daný člen týmu měl právnické vzdělání a rozuměl tak veškerým aspektům podnikání $v$ tomto oboru.

- Facilitační dovednosti - práce ve znalostním managementu obsahuje mnoho diskuzí s lidmi, organizování meetingů apod. Je důležité disponovat lidmi v týmu, kteří tyto dovednosti mají.

- Dovednosti znalostní organizace - pod tento bod spadají dovednosti týkající se explicitních znalostí. Pracovníci musí znát informační management, umět pracovat se systémem správy obsahu (CMS) a ostatními systémy pro podporu znalostí.

- Dovednosti řízení změn - znalostní management obsahuje nepřeberné množství změn, které je zapotřebí vykonat. $\mathrm{K}$ tomu jsou zapotřebí tzv. měkké dovednosti, nebot' činnost pracovníků zahrnuje mimo jiné trénink či mentorink ostatních členů organizace.

- $\quad$ Písemný projev - pracovníci musí disponovat výbornými schopnostmi psaného textu a porozumění různému druhu informací. Musí být schopni zachytit znalosti, vhodně je zpracovat a uložit na vhodné místo. Následně je umět vyhledat a předat vhodnou formou dále.

- IT dovednosti - velmi zásadní dovednost, nebot' téměř veškerá aktivita znalostního týmu je vykonávána prostřednictvím IT technologií. Alespoň jeden člen týmu by měl mít velmi hluboké IT schopnosti a 
znalosti, zejména proto, aby mohl odborně posoudit současné technologie a prípadně navrhnout jejich změnu.

- Znalosti projektového managementu - implementace znalostního managementu se provádí jako projekt. Je důležité disponovat zkušenými lidmi, kteří již získali zkušenost $s$ vedením projektu. Při implementaci je třeba definovat plán, hlavní výstupy, monitorovat pokrok či prípadně přizpůsobit plán změnám apod. [4]

$\mathrm{K}$ hlavním dovednostem je dále zapotřebí, aby měl tým správné hodnoty a chut' posouvat věci $k$ lepšímu. Měl by být vzrušen samotnou myšlenkou něco změnit a inovovat. Zmíněné dovednosti ve většině případů nemúže pokrýt každý jednotlivý pracovník. Je zapotřebí, aby byl tým vhodně namixován tak, aby těmito dovednostmi disponoval jako celek. Volba správného týmu je velmi důležitá, nebot' rozhoduje o stupni úspěšnosti znalostního managementu v organizaci. [4]

\section{Rozpočet a definování cílů znalostního managementu}

Pro implementaci znalostního managementu je nezbytný interní rozpočet, který zajistí finanční pokrytí veškerých aktivit. Rozpočet je třeba jak na samotnou implementaci, tak na následné aktivity, které jsou každodenní záležitostí. Jedná se o kontinuální potřebu financování. Rozpočet by měl být schválen ze strany vrcholového managementu a podpořen tzv. sponzorem. Jak velký rozpočet má být, záleží na velikosti organizace a ochotě managementu alokovat finanční zdroje. Ke stanovení správné výše rozpočtu Ize využít benchmarking. Př́klad výše rozpočtu $v$ závislosti na velikosti organizace charakterizuje následující obrázek: [4]

TAB LE 8.1 The mean annual KM budget against staff size

\begin{tabular}{|lc|}
\hline Organization size (number of staff) & Annual KM budget \\
\hline Tens of staff & $\$ 110,000$ \\
\hline Hundreds of staff & $\$ 125,000$ \\
\hline Thousands of staff & $\$ 950,000$ \\
\hline Tens of thousands of staff & $\$ 1.6$ million \\
\hline SOURCE: Knoco Ltd & \\
\hline
\end{tabular}

Obrázek 3 - Velikost rozpočtu v závislosti na velikosti organizace [4]

$\checkmark$ momentě přiřazení rozpočtu je třeba definovat, co znalostní management přinese organizaci ve finančním vyjádření. $V$ organizacích je zapotřebí pro obhájení aktivit přinést důkazy o prínosnosti, zejména pomocí různých finančních ukazatelů. [4]

Výstupem znalostního managementu je například lepší prístup ke znalostem, jejich uchovávání či snazší distribuce informací. Tyto výstupy vedou k hlavním 
cílům organizace (vyšším ziskům, lepším službám, spokojenějším zákazníkủm apod.). Definování cílů znalostního managementu musí adresovat hlavní cíle organizace tak, aby každý rozuměl, že dané aktivity podporují zmíněné hlavní cíle společnosti. K definování hlavních cílů se využívá např. technika Benefits mapping. Jedná se o grafický způsob, jak zachytit aktivity znalostního managementu s hlavními cíli společnosti. Příklad mapy, spolu s popisem, je uveden na následujícím obrázku. [4]

FIGURE 9.3 A completed benefits map

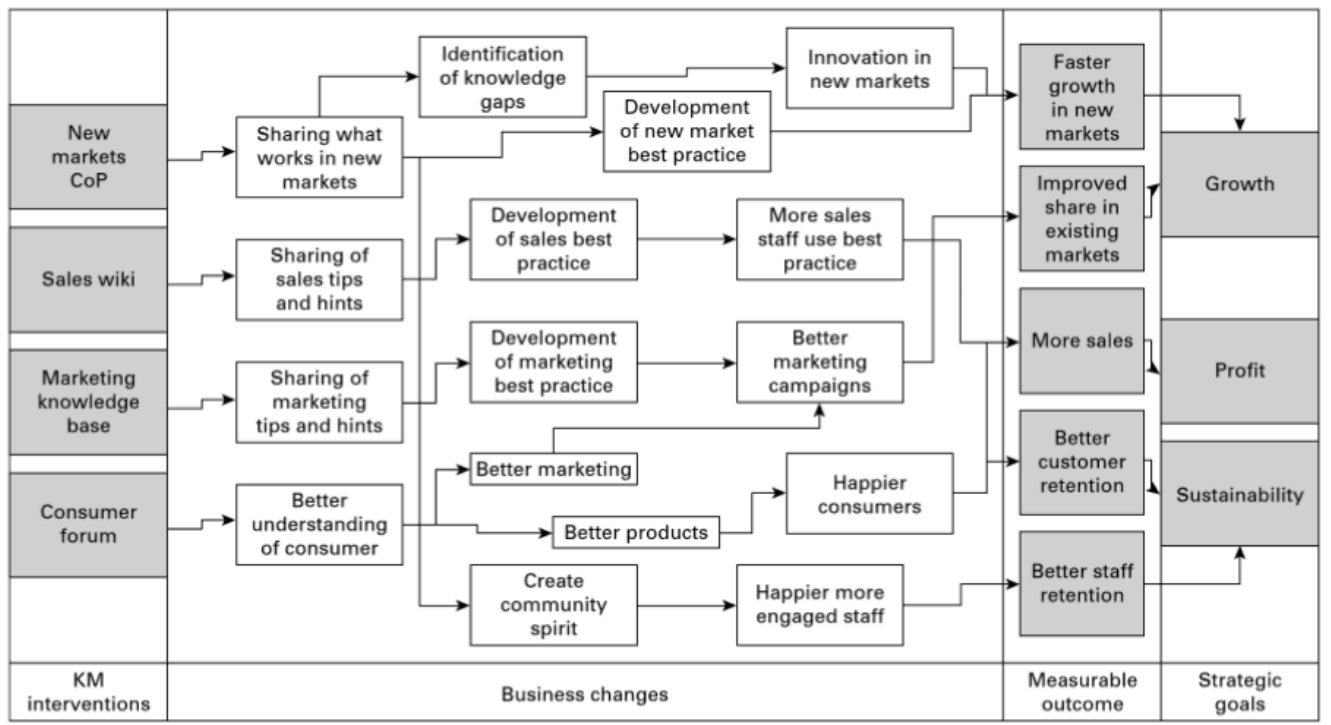

Obrázek 4 - Definování cílů: Benefits mapping [4]

$\checkmark$ levém sloupci jsou definovány aktivity znalostního managementu. Pravý sloupec obsahuje hlavní strategické cíle organizace. Třetí sloupec obsahuje měřitelné výstupy vztažené ke strategickým cílům $v$ posledním sloupci například zvýšený prodej. Druhý sloupec je dedikován pro vytvoření vlastní mapy. Takto vytvořená mapa poskytuje přehledné zobrazení vztahů mezi aktivitami znalostního managementu a hlavními strategickými cíli společnosti. Jedná se o dlouhodobou mapu zobrazující, co znalostní management přinese společnosti do budoucna. Dále Ize k definování cílů využít napríklad široce známou metodiku SMART. [4]

\section{Závěr}

Znalostní management je koncept, který se v poslední době dostává čím dál více do povědomí jak odborné, tak širší veřejnosti. Důvodem je, jak již bylo uvedeno, snaha vyrovnat se se současnou komplexitou informačního světa a naučit se správně vytvářet, uchovávat a sdílet informace $v$ rámci dané organizace. V současnosti existuje mnoho společností, které tento koncept již oficiálně zavedly do své firemní reality. K zavádění se využívá množství metodik, které se dělí dle oboru podnikání společnosti, míry investic, požadovaných výsledků apod. Znalostní management je vhodný nástroj, jak 
podpořit efektivnost vlastní organizace, snižit náklady a zvýšit inovační potenciál organizace.

\section{Poděkování}

Tento článek byl vytvořen za podpory interního grantu Západočeské univerzity číslo projektu je SGS-2018-031 s názvem Optimalizace parametrů udržitelného výrobního systému.

\section{Použitá literatura}

[1] HOLSAPPLE, C. Handbook on Knowledge Management 1: Knowledge matters. 2. vydání, Heidelberg: Springer Science \& Business Media, 2004. ISBN 3540200053.

[2] BUREŠ, V. Znalostní management a proces jeho zavádění: Průvodce pro praxi. Praha: Grada Publishing, 2007. ISBN 978-80-247-1978-8.

[3] TRUNEČEK, J. Znalostní podnik ve znalostní společnosti. 2. vydání, Praha: Professional publishing, 2003. ISBN 8086419673.

[4] MILTON, N., LAMBE, P. The Knowledge Manager's Handbook: A Step-byStep Guide to Embedding Effective Knowledge Management in your Organization. Philadelphia: Kogan Page, 2016. ISBN 978-0749475536. 